\title{
〔62〜63〕 ポリ酢酸ビニルの分岐構造について
}

第 4 報 ポリ酢酸ビニル中の二重結合のポーラログラフによる定量法について

(1956 年 12 月 12 日受理)

井本三郎”・浮田純二"・小南次夫"*

要 旨节酢酸ビニル(PVAc)中に存在する二重結合に過安息香酸(PBA)を反応させ，その消費量をポーラログラ フにて测定し二重結合の定量を試みた。まずPBA単独のポーラログラムは, 酢酸 75一ベンゼン 10一水 $15,0.25 \mathrm{M} \mathrm{NH}_{4} \mathrm{NO}_{3}$

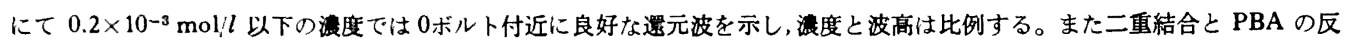
忘は緩僈であるが，二重結合量に対し10２0倍量のPBA を用い2 日間放置することにより定量ができることがわかった。 その測定結果より塊状重合の PVAc では 0.02 0.04 mol\% \% の重結合を有することが明らかになった。

\section{緒言}

酢酸ビニル(VAc)の重合ではモノマーへの移動反応は重要であることは多くの人々によって認められ"

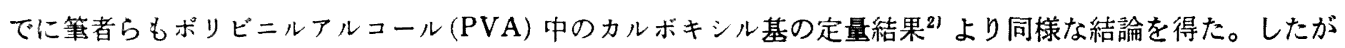
ってVAc の重合で得られたポリ酢酸ビニル(PVAc)は末端に二重結合を有していることは明らかであり,そ

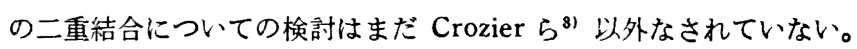

重合体中の二重結合の定量については，Kolthoff ら”のジェン重合体について過安息香酸(PBA)あるいは 一塩化ヨウドを用いての詳細な研究がある。しかし PVAc については Crozier らが一塩化ョウド法に基い て定量を試みたにすぎない。筆者らは過安息香酸を用いポーラログラフによる定量法を検討し二重結合が定 量できることがわかった。本報告では二重結合のポーラログラフによる定量法についてのみ述へ，他の詳細 な問題に対しては次報に詳述する。

\section{实跧方法ならびに考察}

\section{1. 過安息香酸の合成ならびに滴定による定贯法}

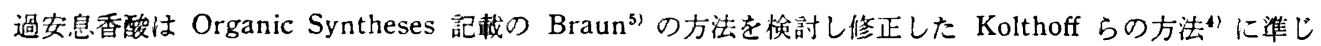
て合成した。すなわち, $100 \mathrm{cc}$ のマイャーに $0.52 \mathrm{~g}$ の金属ナトリウムを適当に冷却しながら無水メタノール $10 \mathrm{cc}$ にとかす。生じたメチラートを塩と氷の寒剤でー $15^{\circ} \mathrm{C}$ に冷却する。再結晶精製した過酸化ベンゾイ ル $5 \mathrm{~g}$ を無水艺硝で乾燥し再三蒸留を行った $20 \mathrm{cc}$ のクロロホルムに溶解した溶液をつくり(同様に十分泠 却しておく)，これをメチラート中に温度が $0^{\circ} \mathrm{C}$ 以上にならない速度で添加する。添加の間マイヤーは強く 絶えずかきまぜる。混合物はミルク状になるが沈殿はあらわれない。反応混合物に約 $15 \mathrm{cc}$ の砕皮を有する 水をよくかきませながら加える。それから混合物を $100 \mathrm{cc}$ の分波漏斗中に移し，かきまぜなから $35 \mathrm{cc}$ の砕 水を有する水を加える。以上のごとくして過安息香酸ンーダを水で抽出する。クロロホルム層は分離し，そ の際水とクロロホルムの境界に集櫴した乳化層は取り捨てる。水の層は安息香酸メチルを取り除くために $10 \mathrm{cc}$ の泠四塩化炭素で2 3 回 洗う。椧四塩化炭素で洗浄する際にも生じた乳化層は取り捨てる。水溶液に

* 倉数レイヨン株式会社富山工場(富山市速町) 
冷 $\mathrm{N}-\mathrm{H}_{2} \mathrm{SO}_{4} 22.5 \mathrm{cc}$ を加え酸性にして過安息香酸ソーダを過安息香酸にした後冷ベンゼン $10 \mathrm{cc}$ で 3 回抽出 する。一緒にしたベンゼン溶液は $5 \mathrm{cc}$ の水で 2 回洗浄し注意媣く分離する。水で洗浄した後粉末の無水艺硝 でベンゼン溶液は乾燥する。乾燥中は光をさけ約 $10^{\circ} \mathrm{C}$ 位にしておく。乾燥後沪過し溶液は $100 \mathrm{cc} に$ 希釈 し、その中 $10 \mathrm{cc}$ を採取して定量する。定量には $0.4 \mathrm{~N}$ の酢酸 $50 \mathrm{cc}$ に $500 \mathrm{~g} / \mathrm{l}$ のヨウドカリ溶液 $2 \mathrm{cc}$ を加 えっこれに PBA のベンゼン溶液 $10 \mathrm{cc}$ を加え混合物はよく振とうした後 $0.1 \mathrm{~N}$ の $\mathrm{Na}_{2} \mathrm{~S}_{2} \mathrm{O}_{3}$ で滴定する。 $0.1 \mathrm{~N}$ の $\mathrm{Na}_{2} \mathrm{~S}_{2} \mathrm{O}_{3} 1 \mathrm{cc}$ は PBA $0.0069 \mathrm{~g}(0.05$ millimol $)$ にあたる。

\section{2. 過安息香酸浴液の安定性}

十分精製したベンゼン溶液中ではPBA はかなり安定である。筆者らが通常 貯蔵しているPBA は 30〜70 millimol $/ l$ のベンゼン溶液で暗所に約 $5 \sim 10^{\circ} \mathrm{C}$ 位 の温度であった。かかる条件下ではPBA は $0.2 \sim 1.0 \% /$ day 程度の分解速度であ った。他の溶媒すなわちメタノール，酢 酸についてのPBAの安定性をしらべた。 その結果を第 1 表に示す。
第 1 表 過安息香酸溶液の安定性 放置温度 $25^{\circ} \mathrm{C}, \mathrm{PBA}$ 濃度 $34.5 \cdot 10^{-8} \mathrm{~mol} / l$

\begin{tabular}{c|c|c}
\hline 溶媒 $($ Vol. \%) & 放置時間 $(\mathrm{hrs})$ & 分解率 $(\%)$ \\
\hline メタノール 50 & 1.00 & 1.37 \\
\cline { 2 - 3 } & 2.30 & 7.91 \\
\hline 酢酸 50 , ベンゼン 50 & 3.40 & 18.00 \\
\hline 酢酸 41.5 , 水 8.5 , ベンゼン 50 & 16.00 & 0.36 \\
\hline
\end{tabular}

\section{3. 恖安息香酸のポーラロクラム}

過安息香酸のポーラログラフ的研究はまだ行われていないので，まずこのもののポーラログラムを研究し た。特に後の PVAc の二重結合の定量を考慮して有機溶媒中におけるポーラログラムをしらぺた。支持塩 としては種々検討の結果硝酸アンモニウムが適当であることがわかった。極大抑制剤としてはTriton X-100 あるいはPVAc をケン化後再酢酸化し後十分精製した PVAc を用いた。

i) 電解液の組成：電解液の組成が酢酸 66.7一ベンゼン20一水 13.3 (容量にて) の場合, PBA は 0 ボル ト付近に上記極大抑制凮で抑制できない極大を有する還元波をあらわす。これらのポーラログラムは再現性 が認められ PBA 濃度の城少とともに極大は小となり，かつ拡散電流の定常部分の波高を測定すれば濃度と 波高との間に比例性が認められる。電解液の組成が酢酸 75一ベンゼン10一水 15 の場合 PBA の濃度が

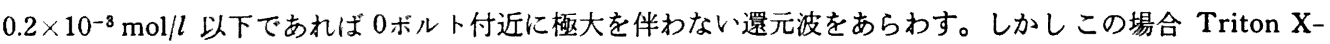
100 は $0.2 \%$ ま までの濃度となしても極大抑制作用はなく, PVAc の場合も $8 \mathrm{~g} / l$ 以上程度の濃度にしなけれ ば十分な抑制作用はあらわれない。

したがって酢酸 75一ベンゼン 10一水 15 , PVAc $8 \mathrm{~g} / l$ 以 上の濃度で良好な還元波が得られたので以下これについて検 討を行った。

ii）極大抑制剤としてのPVAc 濃度の影響：極大抑制 剤としてのPVAc は $8 \mathrm{~g} / \mathrm{l}$ 以上の濃度が必要であるが, そ の濃度変化が波高に及ぼす影響をしらべた。

PBA を $0.134 \times 10^{-8} \mathrm{~mol} / l$ の一定䟴度でしらべた。その 結果を第 2 表に示す。

第 2 娄 PBA のポーラログラムに及ぼす PVAc 濃度の影響

酢酸 75一ベンゼン 10 一水 $15,0.25 \mathrm{M}$ $\mathrm{NH}_{4} \mathrm{NO}_{8}, 25^{\circ} \mathrm{C}, \mathrm{PVA}$ 濃度 $0.134 \times 10^{-8} \mathrm{~mol} / l$

\begin{tabular}{c|c|c}
\hline \hline 試料番号 & PVAc $(\mathrm{g} / l)$ & $i d(\mu \mathrm{A})$ \\
\cline { 1 - 3 } 1 & 11.42 & 0.347 \\
2 & 10.70 & 0.350 \\
3 & 9.94 & 0.347 \\
4 & 8.51 & 0.320 \\
\hline
\end{tabular}

PVAc の濃度は 11〜9g/l 程度の濃度範囲ではほとんど波高に影響がない。この事実は再酢酸化 PVAc 
に二重結合がないという1つの証明となるがこれについては次報に述べる。

iii） PBA 濃度と波高の比例性：極大抑制剂としての PVAc の哄度を $10 \mathrm{~g} / l$ とし，酢酸 75 一ベンゼン

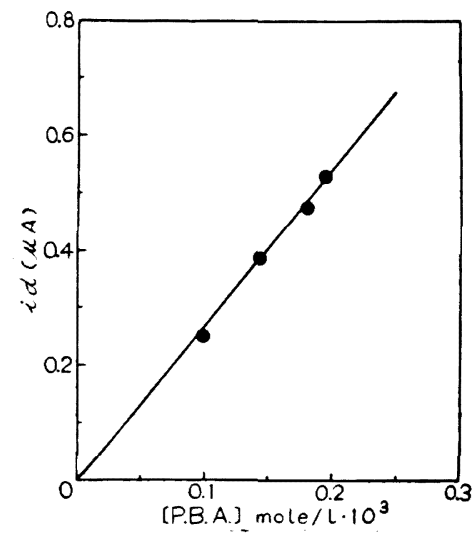

第 1 図 PBA 濃度と波高の関係 10 一水 15 の系に拈いて種々のPBA 濃度でポーラログラムをとっ た。もちろん波高を測定する際には残余電流を補正した。その結 果を第 3 表拉よび第 1 図に示す。

第 3 表 $\mathrm{PBA}$ 濃度と波高の比例性 $0.25 \mathrm{M} \mathrm{NH}_{4} \mathrm{NO}_{8}$, 酢酸 75 一ベンゼン 10 一水 $15,25^{\circ} \mathrm{C}$

\begin{tabular}{c|c|c|c}
\hline \hline 試料番号 & $\begin{array}{c}\text { PBA 濃度 } \\
\left(\mathrm{mol} / l \cdot 10^{8}\right)\end{array}$ & $i d(\mu \mathrm{A})$ & $i d / C$ \\
\cline { 1 - 3 } 1 & 0.097 & 0.250 & 2.58 \\
2 & 0.145 & 0.385 & 2.65 \\
3 & 0.180 & 0.475 & 2.64 \\
4 & 0.194 & 0.527 & 2.71 \\
\hline
\end{tabular}

濃度と波高との間に良好な比例関倸が得られた。

\section{PBA の二重結合への反応条件}

PBA の二重結合への付加は置換基により著しく影響を受ける。Kolthoff ら゙によればジェン重合体で internal double bond は external double bond に比し反応速度がほほ 25 倍大きいことを認めた。しかし ながら適当な反応条件を選べばその全二重結合量の定量が 可能と考えられる。以下これについて検討した。 実験に供したPVAc 試料は B-1（重合温度 $100^{\circ} \mathrm{C}$, 触媒 $2,2^{\prime}$-azo-bis-isobutyronitrile $0.005 \%$ ) および B - (重合温度 $60^{\circ} \mathrm{C}$, 触媒 過酸化ベンゾイル $0.01 \%$ ) である。

i）反応時間の影響：PBA は付加反応の際同時にそれ自体が時間の経過とともに分解して行くので, それらの誤差を取り除 くため空白試験を同時 に実施した。付加反応 はベンゼン溶液中で室 温にて暗所に放置して 行った。なお放置中に おけるベンゼンの逸散 による誤差をなくすた めにペンゼンで飽和し たデシケーター中にお いて行った。その結果 第 4 表 PBA の反応時間の影響

\begin{tabular}{c|c|c|c}
\hline 試料番号 & 初濃度 $\left(\frac{\mathrm{PBA}}{\mathrm{PVAc}} \mathrm{mol} \%\right)$ & 反応時 間 $(\mathrm{hrs})$ & 二重結合量 $(\mathrm{mol} \%)$ \\
\hline B-1 & 0.120 & 25 & 0.006 \\
\hline B-2 & 0.265 & 43 & 0.021 \\
\hline & 67 & 0.019 \\
\hline & 45 & 0.019 \\
\hline & 65 & 0.019 \\
\hline
\end{tabular}
を第 4 表に示す。

第 4 表に示寸通り反応は 2 日間で完結し飽和值に達する。したがって反応時間は 2 日間で十分である。

ii） PBA 初濃度の影響：PBA の, PVAc の二重結合への反応速度はおそいが，室温で 2 日間で完結 することがわかった。したがって反応時間を 2 日とし PBA 初濃度の影響をしらべた。その結果を第 5 表に 示した。 
この結果から二重結合漕度に対し 10２0 倍程度の PBA が必要であることがわかる。

\section{5. 二重結合の定量について}

二重結合に対する PBAの反応は緩慢では あるが，条件を適当に選べば定量が可能であ ることがわかった。しかも Crozier ら¹の 一塩化ヨウドによるヨウド滴定法に比してポ ーラログラフで PBA そのものを直接定量で きるので便利である。定量に供した試料につ いての測定結果は第 6 表に示す通りで, 普通 の条件下の塊状重合によるポリマーは0.02〜 $0.04 \mathrm{~mol} \%$ 程度の二重結合をもっているこ とが明らかになった。

\section{文献}

1）たとえば 桜田, 吉崎：桜田編“ポリ ビニルアルコール”p. 3, 422(1955)； O.L. Wheeler, S.L. Ernst and R.N. Crozier: J. Polym. Sci., 8, 409 (1952) ; ibid., 9, 157 (1952)
第 5 表 PBA 初濃度の影響

\begin{tabular}{|c|c|c|}
\hline 試料番号 & 初濃度 $\left(\frac{\mathrm{PBA}}{\mathrm{PVAc}} \mathrm{mol} \%\right)$ & 二重結合量 $(\mathrm{mol} \%$ ) \\
\hline \multirow{4}{*}{ B-1 } & 0.120 & 0.021 \\
\hline & 0.175 & 0.021 \\
\hline & 0.263 & 0.042 \\
\hline & 0.316 & 0.045 \\
\hline \multirow{3}{*}{ B-2 } & 0.265 & 0.019 \\
\hline & 0.316 & 0.021 \\
\hline & 0.407 & 0.021 \\
\hline
\end{tabular}

第 6 表 PVAc の重合条件と二重結合量

\begin{tabular}{|c|c|c|}
\hline 試料番号 & B-1 & B-2 \\
\hline 重 合 型 式 & 塊 状 & 塊 状 \\
\hline 触 媒 & $\mathrm{AZN}, 0.005 \%$ & $\mathrm{BPO}, 0.01 \%$ \\
\hline 重合温度（ $\left.{ }^{\circ} \mathrm{C}\right)$ & 100 & 60 \\
\hline 重合率（\%) & 37 & 31 \\
\hline $\bar{P}_{A c}$ & 2820 & 8120 \\
\hline 二重結合 $\left(\mathrm{mol}^{o}, c^{\prime}\right)$ & 0.043 & 0.021 \\
\hline
\end{tabular}

2) 井本, 浮田, 小南: 高化, 14, 127 (1957)

3) O.L. Wheeler, S. L. Ernst and R. N. Crozier : J. Polym. Sci., 8, 409(1952); O. L. Wheeler, E. Lavin and R.N. Crozier: J. Polym. Sci., 9, $157(1952)$

4) I. M. Kolthoff and T.S. Lee: J. Polym. Sci., 2, $206(1947)$; I.M. Kolthoff, T.S. Lee and M.A. Mairs: J. Polym. Sci., 2, $220(1947)$; T.S. Lee, I.M. Kolthoff and E. Johnson: Anal. Chem., 22, 995(1950)

5) G. Braun : in Organic Syntheses, Coll. Vol. I, 2nd ed. p. 431 (1941)

\section{Branched Structure of Polyvinyl Acetate}

\section{Polarographic Determination of Double Bonds in Polyvinyl Acetate}

\section{By Saburō Imoto, Junji Ukida and Tsugio Kominami}

Double bonds in polyvinyl acetates can be determined polarographically by the measurement of the residual perbenzoic acid (PBA) after the reaction between double bond and PBA. Polarograms of PBA, in acetic cid 75-benzene 10-water 15 (by volume) with $0.25 \mathrm{M}$ ammonium nitrate as a supporting salt, showed a good reducing wave at about 0 volt only with solution of $0.2 \times 10^{-8} \mathrm{~mol} / l$ or less, and its wave height was propotional to the concentration of PBA. By adding $10 \times 20$ times excess of PBA over double bond in PVAc and standing at room temperature in the dark for 2 days, reaction went to completion. By this method, PVAc was found to contain $0.02 \sim 0.04 \mathrm{~mol} \%$ double bonds. 